\title{
Innovations in the Educational Process and Pedagogical Technologies under the Influence of Crisis Phenomena and Global Digitalization
}

\author{
NATALIIA MAKHYNIA ${ }^{1}$, YAROSLAV KICHUK ${ }^{2}$, OLENA PTASHCHENKO ${ }^{3}$, KATERYNA KYRYLENKO ${ }^{4}$, \\ KATERYNA HORCHYNSKA ${ }^{5}$, VIACHESLAV RIZNYK ${ }^{6}$ \\ ${ }^{1}$ Department of Humanitarian Technologies, CHERKASY STATE TECHNOLOGICAL UNIVERSITY, UKRAINE. \\ ${ }^{2}$ Department of Ukrainian and World History and Culture, IZMAIL STATE UNIVERSITY OF HUMANITIES, \\ UKRAINE. E-mail: kichuk.yaroslav@ukr.net \\ ${ }^{3}$ Department of International Business and Economic Analysis, S. KUZNETS KHARKIV NATIONAL UNIVERSITY OF \\ ECONOMICS, UKRAINE. \\ ${ }^{4}$ Department of Philosophy and Pedagogy, KYIV NATIONAL UNIVERSITY OF CULTURE AND ARTS, UKRAINE. \\ ${ }^{5}$ Department of Professional Education and Life Safety, T.N. SHEVCHENKO NATIONAL UNIVERSITY "CHERNIHIV \\ COLEHIUM", UKRAINE. \\ ${ }^{6}$ Department of Vocational Education, HRYHORII SKOVORODA UNIVERSITY IN PEREIASLAV, UKRAINE.
}

\begin{abstract}
Innovations in the educational process are necessary because the entire country's future well-being depends on the level of education of young people. Pedagogical technologies are being improved to provide high-quality modern education. In their study, the authors studied the features of innovations in the educational process and pedagogical technologies, the impact of the crisis and global digitalization on it, as well as global trends. The authors determined that the dominant processes and functions for acquiring new knowledge and transferring it to the economy's production sectors are increasingly organized according to the principle of networks and proposed the features and algorithm for the formation of a pedagogical (educational) cluster. To calculate the effectiveness of such a cluster, the authors have developed a complex system of indicators. The recommendations proposed in the study will help universities understand the clustering process, realize its importance, outline development paths and their place in the clustering of the educational process.
\end{abstract}

Keywords: educational process, global digitalization, innovation, pedagogical cluster.

JEL Classification: 123, 125, A31 


\section{Introduction.}

Innovation in the field of education is understood as everything related to the implementation of advanced pedagogical experience in practice. Occupying a top place in modern science, the educational process aims to transfer knowledge, abilities, and skills to students, at the formation of personality, citizenship. The changes are dictated by time, a change in attitudes towards learning, upbringing, and development.

Innovative technologies in education make it possible to regulate learning, increasing the efficiency of the teaching and educational process (Omelyanenko et al., 2020). Innovative behaviour does not offer the student to adapt to the new conditions of educational interaction simply; it implies the formation of his individuality, self-development (Olshanska et al., 2019). It is important to understand that innovative education is, first of all, a way to bring up a harmonious personality. Pedagogical innovations should not bring "ready-made templates" to students; innovations in education are aimed at the actual increase in the student's intellectual level. And a teacher who has got rid of "complexes" and psychological barriers should become a full-fledged participant in innovative transformations. The purpose of the teacher's innovative activity is to change the student's personality compared to the traditional system. These changes become possible through the introduction of new didactic and educational programs into professional activities. The development of the ability to find motivation for their actions, independently navigate the information received, the formation of creative non-standard thinking, and students' development through the full disclosure of their natural abilities, using the latest science and practice achievements, are the main goals of educational innovation.

\section{Theoretical basis.}

\subsection{Innovations in the educational process and pedagogical technologies.}

The concepts of "innovation" and "innovation (novation)" have the same meaning, in addition, we can say that innovation is associated with the creation of all kinds of designs and, therefore, is a process of implementation, implementation of this very innovation in the social or industrial environment. Translated from Latin, innovation means the entry of the new into a certain field of activity, implantation into it and the generation of a whole series of changes. Accordingly, innovative activity presupposes a system of interrelated types of any individual or collective activity in a broad sense. For example research activity implies obtaining new knowledge about the nature of phenomena and how this phenomenon can be recreated in the laboratory; project activities related to the development of instrumental and technological knowledge about how, on the basis of existing scientific knowledge, you can get something that will actually perform specific functions; or educational activities, the essence of which boils down to a competency-based approach in the professional development of an individual based on knowledge/experience in the implementation of project or research activities. Thus, "innovative education" is a type of educational activity capable of self-development and change depending on external conditions. It also allows creating conditions for the full development of all its participants, i.e. innovative education is a developing and selfdeveloped education.

In turn, "innovative educational technology" is a system consisting of three interrelated components (Fig. 1).

Thus, innovative technologies combine both interactive forms of education and information and communication technologies (ICT). 
Figure 1. Structure of innovative educational technologies

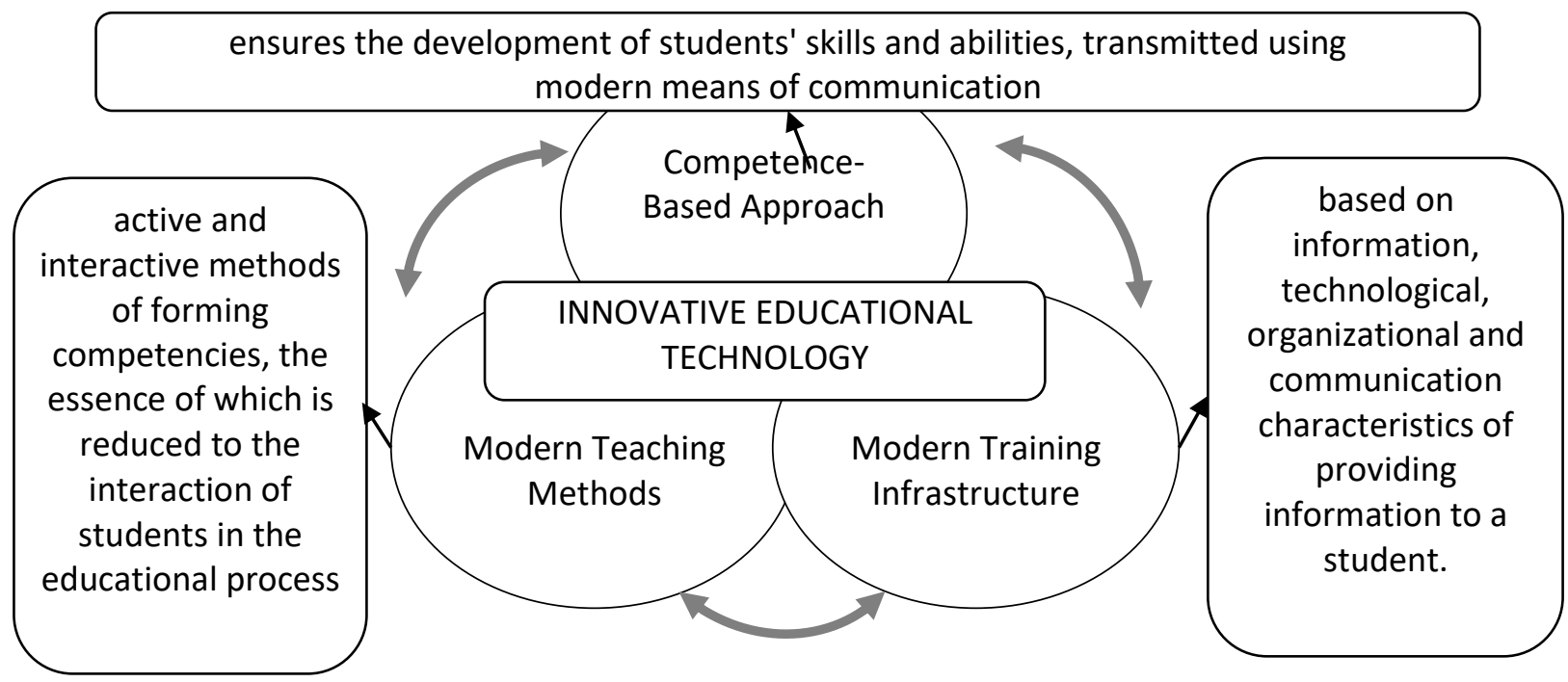

The innovative activity of a university can have several directions (Fig. 2).

When organizing the process, it is important to give only the basic guidelines for cognitive dialogue, individual self-expression, individual awareness, general and professional erudition, and scientific research culture. In assessing the completeness of mastering the content of the subject, we are guided by the level of professional mentality (mental skills and spiritual meanings), expectations and attitudes, individually revealed in research activities, and the implementation of competencies:

- possession of the ability for abstract thinking, for independent development of new areas of professional training;

- readiness to carry out professional communication to solve professional problems, to manage research work;

- the ability to analyze the results of scientific research, apply them in solving specific research problems in the field of science and practice;

- manifestation of creative skills for the independent solution of research problems.

It should also be noted that in the aggregate, absolute leadership is given to general (general social, legal) preventive measures as the most effective.

\subsection{The Impact of Crisis and Global Digitalization.}

Crisis phenomena are an integral part of any system. Crises occur with different frequency in various spheres of human activity; by now, a wide classification of situations has been formed, characterized by various factors. Most researchers interpret the crisis as a kind of negative, but natural phenomenon for a market economy, characterized by a deterioration in the indicators of key areas of public life but contributing to the renewal of the qualitative characteristics of the system. Digitalization has the same properties - a qualitative restructuring of the system. 
Nataliia Makhynia, Yaroslav Kichuk, Olena Ptashchenko, Kateryna Kyrylenko, Kateryna Horchynska,

Viacheslav Riznyk

Figure 2. Directions of innovative activity of the university

\begin{tabular}{|c|c|c|}
\hline \multicolumn{3}{|c|}{ THE UNIVERSITY'S INNOVATIVE ACTIVITY } \\
\hline & $\begin{array}{l}\text { Intra-subject } \\
\text { innovation }\end{array}$ & $\begin{array}{l}\text { These are innovations that are implemented within the subject and are } \\
\text { associated with the specifics of teaching. This is usually due to various } \\
\text { author's methods and the transition to new educational and methodological } \\
\text { complexes (for example, simulators for professional development). }\end{array}$ \\
\hline & $\begin{array}{l}\text { Methodical } \\
\text { innovations }\end{array}$ & $\begin{array}{l}\text { These are innovations associated with introducing non-traditional } \\
\text { pedagogical technologies into the educational process, such as case } \\
\text { technologies, role-playing and business games, project activities, a point- } \\
\text { rating system for assessing knowledge, etc. }\end{array}$ \\
\hline & $\begin{array}{l}\text { Administrative } \\
\text { innovation }\end{array}$ & $\begin{array}{l}\text { These are innovations affecting decision-making by managers of various } \\
\text { levels and contributing to the effective management of educational } \\
\text { institutions (for example, the implementation of a quality management } \\
\text { system). }\end{array}$ \\
\hline & $\begin{array}{l}\text { Ideological } \\
\text { innovation }\end{array}$ & $\begin{array}{l}\text { These are the so-called innovations of the renewal of consciousness, which } \\
\text { are the fundamental principle of all other innovations, and the } \\
\text { understanding of which contributes to the rational and correct use of the } \\
\text { introduced approaches that lead to renewal. }\end{array}$ \\
\hline
\end{tabular}

In the information age, it has historically taken shape that the dominant processes and functions for acquiring new knowledge and transferring it to the economy's production sectors are increasingly organized according to the principle of networks (Miśkiewicz, 2018). It is networks that constitute the new social morphology of our societies, and the spread of "network" logic has a significant impact on the course and results of processes related to production, everyday life, culture and power (Kwilinski et al, 2020).

In this regard, at present in the world, flexible network structures are considered as a new tool for increasing the competitiveness of education, developing their innovative potential - clusters and networks created based on multilateral agreements and uniting universities, innovative firms, scientific and educational organizations based on integration.

Integration-based network partnerships are known to create the following drivers of progress:

- lack of physical restrictions on growth;

- fast diffusion and assimilation of knowledge;

- creation of new knowledge and new tools;

- ensuring its own identity of network partnerships;

- joint management of collective knowledge;

- maximum opportunities for assimilation of the most innovative valuable implicit (hidden) knowledge (tacit knowledge), which is not formalized and cannot be learned in the traditional way (translation, codification, digitization, preservation).

Thus, educational organizations' integration can be viewed as a pooling of economic entities' efforts without loss of autonomy. One of the options for such interactions is the cluster approach, an association of economic entities in a limited area with authorities' assistance with the allocation of a coordinating centre based on formal and informal agreements to establish stably diversified economic and other ties between organizations. Cluster integration expansion tendencies contribute 
to the creation of an environment for the distribution of "points of growth" existing in the regions in different industries, and the receipt of a synergistic effect as a result of the cooperation of individual organizations along interaction chains. The effectiveness of cluster integration has been proven theoretically and confirmed by numerous foreign and domestic examples (Tvaronaviciene et al., 2015; Ding \& Cai, 2017; Pustynnikova \& Uskova, 2017;).

According to Michael Porter's definition, a cluster is a group of geographically adjacent interconnected companies (suppliers, manufacturers, intermediaries) and related organizations (educational institutions, government bodies, companies that determine the infrastructure) operating in a specific area and complementing each other (Porter, 2001). Porter proposes not an artificial creation of clusters from above, but their detection in real life and support by government agencies and research institutes. The concept of development of regional clusters was developed by M. Porter's follower M. Enright, in which he defined a cluster as a geographically delineated agglomeration of interconnected firms and organizations (Enright, 1992).

In this case, the coordination of business interests in integrated systems will allow interaction participants to obtain a synergistic effect, which will manifest itself:

- in the efficient use of resources and, consequently, in reducing costs;

- flexible manoeuvring;

- in the possibility of more significant attraction and mobilization of resources;

- strengthening the exchange of knowledge between the participants in the interaction;

- ensuring mutual access of participants to qualified labour

- in the general growth of competitiveness;

- in the stability and authority of the integration participants.

This confirms the authors' opinion that under the influence of the crisis and global digitalization, clusters' formation is a necessary innovation in the educational process.

\section{Results and discussion.}

The effectiveness of a country/region's socio-economic development is largely determined by the degree of development of innovative processes. Both the acquisition of new knowledge and its transfer to the social sphere and the economy's production sectors are equally essential components.

The above-considered impact of the crisis and global digitalization, a distinctive feature of the qualitative restructuring of the system, the peculiarities of the cluster system, allowed the authors to form certain developments as a tool of the educational innovation process and pedagogical technologies (Fig. 3).

Among the essential conditions and mechanisms for managing the development of a pedagogical cluster integrated system, one should highlight:

- transformation of the general goals of the pedagogical (educational) cluster into the goals and objectives of the subjects of interaction;

- positioning the activities of the subjects of interaction concerning the goals;

- determination of the state of the subject of interaction concerning the cluster of goals and objectives assigned to him;

- determination of the possibilities of bringing the state of the subjects of interaction in line with the set goals and objectives by changing the conditions and mechanisms of resource support for their activities;

- formation and adoption of collective management decisions.

To assess the cluster's effectiveness, we propose a detailed system of indicators (Table 1). 
Figure 3. Educational cluster: factors and formation algorithm

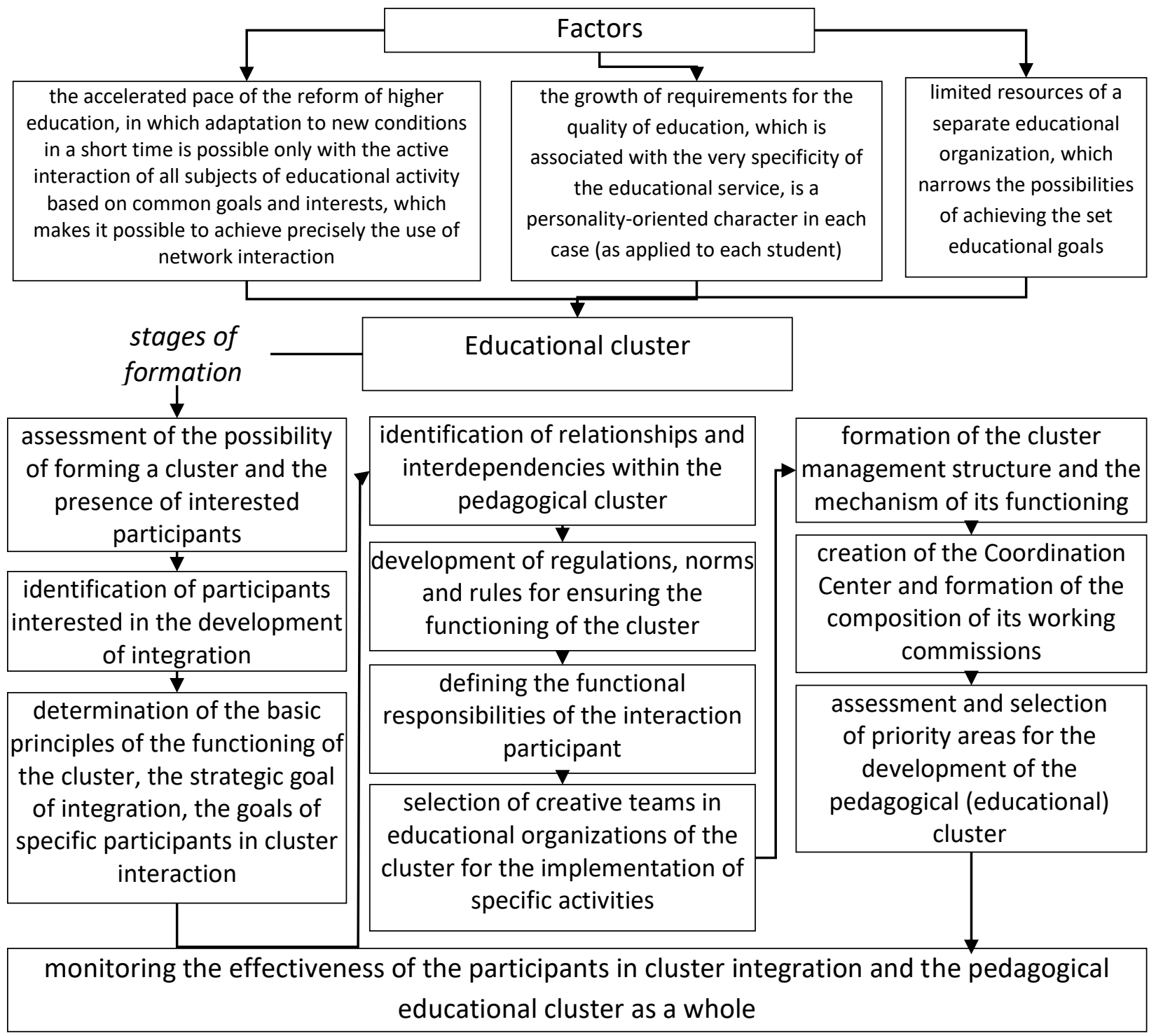

The effectiveness of the pedagogical cluster is calculated according to the final formula:

$$
\begin{gathered}
E_{p c}=\left[\left(k_{1}+k_{2}+k_{3}\right)+\left(k_{4}+k_{5}\right)+\left(k_{6}+k_{7}+k_{8}\right)+\left(k_{9}+k_{10}+k_{11}\right)\right. \\
\left.+\left(k_{12}+k_{13}\right)+0\right] \leq 5
\end{gathered}
$$

One of the effective implemented clustering tools is Cluster Mapping. The US Cluster Map Project is a national business initiative that provides more than 50 million open sources of information on US industrial clusters and regional business environments to stimulate economic growth and national competitiveness (Cluster Mapping, 2021).

This resource provides a modern online environment, integrating baseline data and costeffectiveness indicators to shed light on the region's strengths and capabilities and enable areas and businesses to make decisions. With a wide range of organizations, the platform also seeks to connect businesses with organizations that promote their clusters and allow users to share and discuss best economic development, policy, and innovation practices. The project provides a database of cluster maps based on leading research results. 
Innovations in the Educational Process and Pedagogical Technologies under the Influence of Crisis Phenomena and Global Digitalization

Table 1. Indicators for assessing the effectiveness of the pedagogical cluster

\begin{tabular}{|c|c|c|c|}
\hline $\begin{array}{c}\text { Performance } \\
\text { evaluation criteria }\end{array}$ & $\begin{array}{c}\text { Influence } \\
\text { factor on the } \\
\text { characteristic } \\
\text { (Ki) }\end{array}$ & Factors influencing the criteria & Assessment methodology \\
\hline
\end{tabular}

1. Availability of competitive universities (K1)

\begin{tabular}{|c|c|c|c|}
\hline $\begin{array}{c}\mathrm{k} 1 \text { - determination of } \\
\text { the current } \\
\text { development } \\
\text { potential of the } \\
\text { university }\end{array}$ & 0,4 & - average level of students & $\begin{array}{c}\text { Calculation of the coefficient of } \\
\text { increasing the volume of products } \\
\text { (services) produced by enterprises at } \\
\text { full load }\end{array}$ \\
\hline $\begin{array}{c}\text { k2 - the influence of } \\
\text { the universities of the } \\
\text { cluster on the industry } \\
\text { of the region }\end{array}$ & 0,4 & $\begin{array}{c}\text { - occupied share of the domestic } \\
\text { market }\end{array}$ & $\begin{array}{c}\text { Calculation of the total volume of } \\
\text { services in the volume of services by } \\
\text { industry }\end{array}$ \\
\hline $\begin{array}{c}\text { k3 - the image of the } \\
\text { cluster's universities in } \\
\text { the industry }\end{array}$ & 0,2 & $\begin{array}{c}\text { - the level of business activity of } \\
\text { universities in the cluster; }\end{array}$ & Expert review \\
\hline
\end{tabular}

2. Implementation of innovative projects (K2)

\begin{tabular}{|c|c|c|c|}
\hline $\begin{array}{c}\mathrm{k} 4 \text { - degree of } \\
\text { innovation }\end{array}$ & 0,5 & $\begin{array}{c}\text { - an increase in the number of } \\
\text { innovations in the industry after } \\
\text { the creation of the cluster; }\end{array}$ & $\begin{array}{c}\text { Assessment of the revitalization of } \\
\text { universities, an increase in available } \\
\text { funds for investment in new } \\
\text { technologies }\end{array}$ \\
\hline $\begin{array}{c}\text { k5 - commercialization } \\
\text { of new technologies }\end{array}$ & 0,5 & - introduction of new technologies & $\begin{array}{c}\text { Expert assessment of the number of } \\
\text { innovations in the industry after the } \\
\text { creation of the cluster }\end{array}$ \\
\hline
\end{tabular}

3. Social development in the regions (K3)

\begin{tabular}{|c|c|c|c|}
\hline K6 - educational level & 0,4 & $\begin{array}{c}\text { - an increase in the number of } \\
\text { people with higher / secondary } \\
\text { specialized education after the } \\
\text { creation of the cluster; }\end{array}$ & $\begin{array}{c}\text { change in the proportion of residents } \\
\text { with secondary education }\end{array}$ \\
\hline K7 - longevity index & 0,3 & $\begin{array}{c}\text { - increase in life expectancy after } \\
\text { the creation of a cluster; }\end{array}$ & $\begin{array}{c}\text { change in average life expectancy for } \\
\text { the analyzed period }\end{array}$ \\
\hline K8 - material well- \\
being index
\end{tabular}


Nataliia Makhynia, Yaroslav Kichuk, Olena Ptashchenko, Kateryna Kyrylenko, Kateryna Horchynska, Viacheslav Riznyk

\begin{tabular}{|c|c|c|c|}
\hline & & & $\begin{array}{l}\text { we can assume that collaboration } \\
\text { within the cluster members is } \\
\text { developed, and conclude that creating } \\
\text { a cluster has a positive effect on } \\
\text { increasing the level of cooperation } \\
\text { among the participants. }\end{array}$ \\
\hline $\begin{array}{l}\mathrm{k} 10 \text { - the creation of } \\
\text { the infrastructure } \\
\text { necessary for the } \\
\text { development of the } \\
\text { cluster }\end{array}$ & 0,3 & $\begin{array}{l}\text { - the ability to create the } \\
\text { necessary infrastructure }\end{array}$ & \multirow[t]{2}{*}{ Expert review } \\
\hline $\begin{array}{l}\text { k11 - reaching a new } \\
\text { level of management }\end{array}$ & 0,3 & $\begin{array}{l}\text { - the ability of the heads of the } \\
\text { university of the cluster to reach a } \\
\text { higher level of management }\end{array}$ & \\
\hline \multicolumn{4}{|c|}{ 5. Geographic proximity of cluster members, the correct choice of cluster members and their number (K5) } \\
\hline $\begin{array}{l}\text { k12 - geographic } \\
\text { proximity of cluster } \\
\text { members }\end{array}$ & 0,5 & $\begin{array}{l}\text { - territorial location of cluster } \\
\text { members }\end{array}$ & $\begin{array}{l}\text { The proximity of the location of the } \\
\text { cluster members is estimated }\end{array}$ \\
\hline $\begin{array}{l}\mathrm{k} 13 \text { - the correct } \\
\text { choice of cluster } \\
\text { members and their } \\
\text { number }\end{array}$ & 0,5 & $\begin{array}{c}\text { - selection of the minimum } \\
\text { number of enterprises with the } \\
\text { maximum share in the domestic } \\
\text { market }\end{array}$ & $\begin{array}{l}\text { The share of each university in the } \\
\text { industry is estimated (by indicators: the } \\
\text { number of students, the volume of } \\
\text { commercialization of developments, } \\
\text { etc.) }\end{array}$ \\
\hline Maximum score & \multicolumn{3}{|l|}{5,0} \\
\hline
\end{tabular}

Figure 4. An example of building a cluster (Cluster Mapping, 2021)

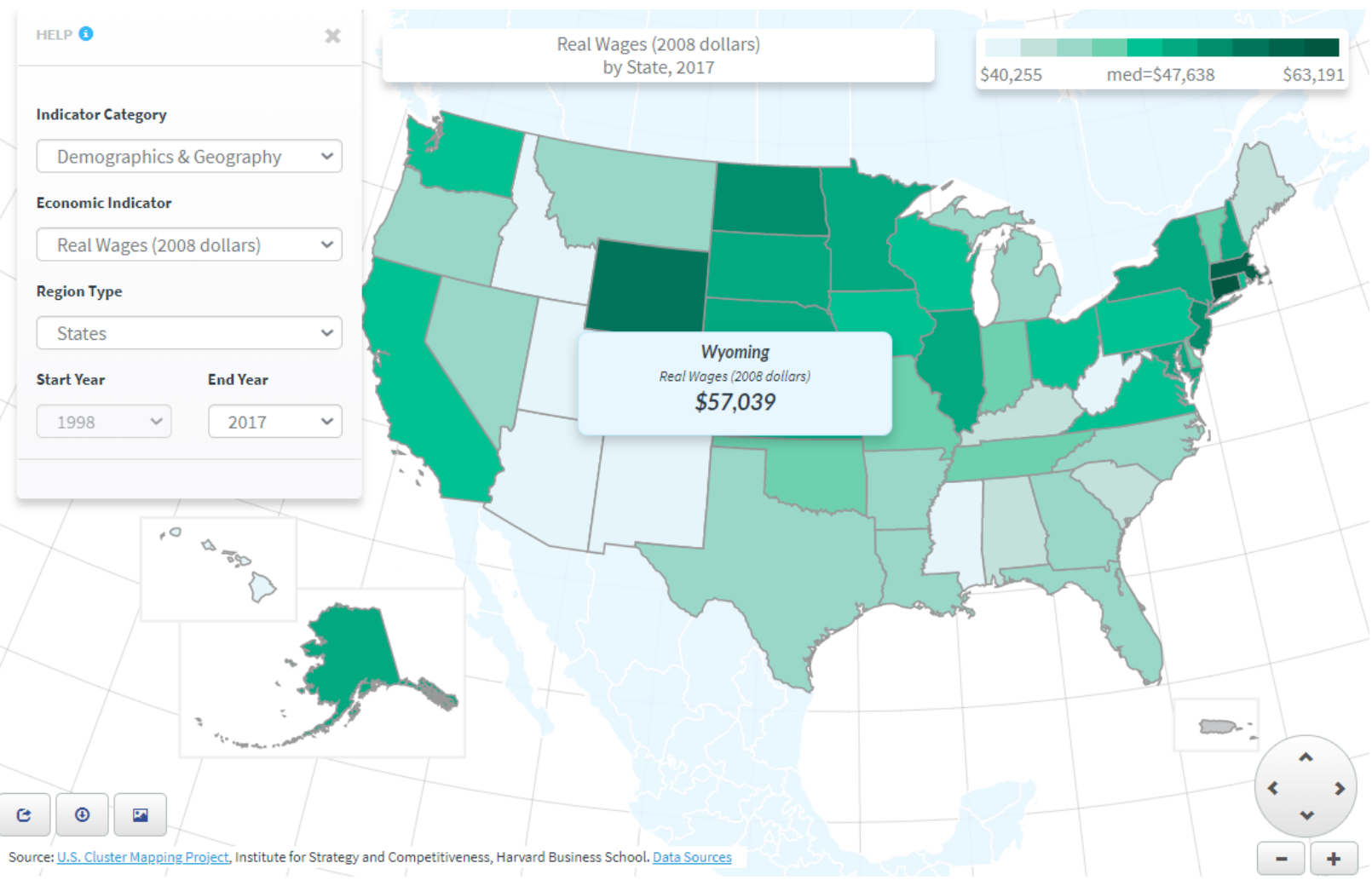


The project is highly optimized, invests in a modern website and allows private and public entities to effectively use cluster map data (Fig. 4). This web tool provides information on the existence and functioning of the cluster, as well as regional economic indicators, business environment quality and regional characteristics. The platform's main element is the organizational register, which provides a network of practitioners to learn about current initiatives across the country and share best practices.

Ukraine should learn from this experience by expanding its functionality. So, for example, when choosing a speciality, you can immediately see which universities are preparing students for this speciality, with whom they cooperate. This will stimulate universities to expand their interaction with stakeholders. On the site, you can immediately see how the university develops science (cooperation with scientific institutions and organizations) and employment prospects (collaboration with the economic sector) to ensure a competitive advantage.

\section{Conclusion.}

Innovations in the educational process and pedagogical technologies are necessary because the future well-being of the entire country depends on young people's level of education. Changes are continually taking place globally, both positively - global digitalization, acceleration of all processes, and negative - crisis phenomena, destabilization processes that affect the educational process. Even from negative phenomena, universities should seek opportunities for development, growth in the quality of education, and the introduction of innovations.

The recommendations proposed in the study will help universities understand the clustering process, realize its importance, outline development paths and their place in the clustering of the educational process.

The main difficulties in the formation of a pedagogical (educational) cluster today include problems with the coordination of the activities of executive authorities and educational organizations in the field of cluster policy and the limitation of the set of tools for financial support of cluster projects in the field of education from the authorities.

\section{References}

1. Cluster Mapping, 2021. Available at: http://www.clustermapping.us/

2. Ding, J., \& Cai, J. (2017). Efficient MIMO-NOMA Clustering Integrating Joint Beamforming and Power Allocation in GLOBECOM 2017 - 2017 IEEE Global Communications Conference, DOI: 10.1109/GLOCOM.2017.8254639

3. Enright, M. (1992). Why Clusters are the Way to Win the Game? Word Link, 5, 46-52.

4. Kwilinski, A., Litvin, V., Kamchatova, E., Polusmiak, J., \& Mironova, D. (2020). Information Support of the Entrepreneurship Model Complex with the Application of Cloud Technologies. Journal of Entrepreneurship Education, 23(SI1), 1-9. Retrieved from https://www.abacademies.org/articles/Information-support-of-the-entrepreneurship-1528-265123-S1-557.pdf

5. Miśkiewicz, R. (2018). The Importance of Knowledge Transfer on the Energy Market. Polityka Energetyczna, 21(2), 49-62. http://dx.doi.org/10.24425\%2F122774

6. Olshanska, O. Gumennykova, T., Bila, O., Orel, V., Perova, S., \& Ivannikova, M. (2019). Building a competency model student training. International Journal of Engineering and Advanced Technology, 8(6), pp. 2689-2695.

7. Omelyanenko, V., Kudrina, O., Shevtsova, H., Prokopenko, O., \& Petrenko, V. (2020). ICT for innovative education and science: Smart environment for networked strategies in 43rd International Convention on Information, Communication and Electronic Technology, MIPRO 2020 - Proceedings, 2020, pp. 727-730, 9245133. 
8. Porter, M. (2001). Regions and the New Economics of Competition. Global City-Regions: Trends, Theory, Policy, Allen J. Scott (ed). Oxford: Oxford University Press, 2001, pp. 139-157.

9. Pustynnikova, E.V., \& Uskova, E.O. (2017). The Formation of Competitive Advantages for Corporate Structures Based on the Cluster Integration, Economy of Region, 13(2), 500-510, DOI: 10.17059/2017-2-15

10.Tvaronaviciene, M., Razminienè, K., \& Piccinetti, L. (2015). Cluster efficiency study through benchmarking, Journal of Entrepreneurship and Sustainability Issues, 3(2), pp. 120-128 DOI: 10.9770/jesi.2015.3.2(0) 